\title{
Temira Pachmuss, 1927-2007
}

Temira Pachmuss, emeritus professor at the University of Illinois, Urbana-Champaign, died at her home in Urbana on 1 May 2007 after a brief illness. Temira Andreevna, as she was known to her acquaintances and Russian-speaking students, was born on 24 December 1927 in Vask-Narva, Estonia, and educated in Germany, Australia, and the United States. She received BA and MA degrees from the University of Melbourne $(1954,1955)$, and her PhD from the University of Washington, Seattle (1959). Early in her career she taught at the University of Michigan and the University of Colorado, but in 1960, she accepted a position at the University of Illinois where she remained for the duration of her academic career until her retirement in 1999.

Temira Andreeva wrote or edited twenty-eight books focusing, in the main, on the cultural achievements of the Russian emigration of which she was part. Her central area of research was the work and life of Zinaida Gippius, with whom she identified for her intellect, wit, and talent. Temira Andreeva laid the foundation for most of the western scholarship exploring Gippius that would follow, and she did this as feminism was becoming popular, but without resorting to its more radical strategies. Rather than sensationalizing the more vivid moments of Gippius's biography, she emphasized the elements of poetic achievement and intellectual courage that allowed Gippius to stand at the side and sometimes above the best talents of the Silver Age. Her research was grounded in meticulous archival work. She published a selection of Gippius's short stories in translation, wrote a biography of the poet, and edited her diaries and a collection of her letters.

Her work with Gippius led Temira Andreevna to further research involving the life and works of Dmitrii Merezhkovskii. As with his wife, her publications dealing with Merezhkovskii included both analytical texts, most notably D.S. Merezhkovsky in Exile (1990), and editorial labors in preparing Malen'kaia Tereza (1984). Gippius's and Merezhkovskii's contributions to Russian émigré culture after the revolution and roughly up to World War II formed the foundation for Temira Andreeva's numerous publications centered on the Parisian and Baltic diasporas, including A Russian Cultural Revival: A Critical Anthology of Émigré Literature before 1939 (1981), A Moving River of Tears: Russia's Experience in Finland (1992), and Russian Literature in the Baltic between the World Wars (1988). The first book continued the work of a prior collection, Women Writers in Russian Modernism: An Anthology (1978), while the last two explored Russian-Baltic relations in terms of literary and cultural intersections. Temira Andreevna analyzed both the mutual debts and disagreements of the Russians and the Finns and Estonians, and through the careful exploration of historical sources and literary documents, demonstrated the unvarnished and sometimes highly productive processes of cross-cultural interaction.

Recognition of her scholarship and cultural contributions followed when the Estonian government awarded her the Medal of the Order of the White Star on 30 March 2001 in ceremonies at the Estonian Embassy in Washington, D.C. Although she had received numerous other honors, including fellowships and grants given by the Fulbright commission, the National Endowment for the Humanities, the American Philosophical Society, and the American Council of Learned Societies, the Estonian award served as a fitting culmination to a distinguished career. Her influence, as that of the work of her colleague and close friend Victor Terras in related areas, will continue to be felt in Slavic and Baltic studies as long as Gippius, Merezhkovskii, Russian émigré culture, and cross-cultural issues retain their rightful places in scholarly interest.

NicHOLAS RZHEVSKY

State University of New York, Stony Brook August 2007 